Naukowe Centrum Obrazowania Biomedycznego Instytut Fizjologii i Patologii Słuchu, Warszawa Bioimaging Research Centre Institute of Physiology and Pathology of Hearing, Warszawa h.cygan@ifps.org.pl

\title{
Reprezentacja Ja u wysokofunkcjonujących osób z autyzmem - przegląd badań z wykorzystaniem metod neuroobrazowania mózgu
}

\section{Self-Representation in High-Functioning Autism - Review of Neuroimaging Experiments}

\begin{abstract}
Development of self-representation is vitally important for internalizing typical behavior and for building interpersonal relationships. Taking into account the neuronal underpinnings of cognitive functions, symptoms of autism spectrum disorders (ASD) have been related to impairments of neuronal systems underlying self-perception. The present paper reviews research implementing functional magnetic resonance imaging (fMRI) and electroencephalography (EEG) to study the neural mechanisms of self-related information processing in persons with ASD. These experiments address the psychological aspects of self-representation associated with the appraisal of one's own traits and of the symbolic, as well as physical, representation of self in response to the perception of one's own name and face. Furthermore, results of a study that employed fMRI to assess the perception of changeability of personal traits across time among subjects with ASD are also included. The studies under review support the hypotheses of atypical neuronal mechanisms of cognitive self-representation and anomalous perception of social feedback in persons diagnosed with ASD.
\end{abstract}

Keywords: autism spectrum, ASD, self, self-representation, neuronal mechanisms, review, prefrontal cortex, cingulate gyrus, fMRI, EEG

Słowa kluczowe: spektrum autyzmu, ASD, reprezentacja Ja, neuronalne mechanizmy, przegląd literatury, kora czołowa, zakręt obręczy, fMRI, EEG

\section{WSTĘP}

Autyzm jest złożonym zaburzeniem rozwojowym, którego objawy kliniczne, określone w najnowszych klasyfikacjach diagnostycznych, dotyczą interakcji społecznych i komunikacji oraz charakterystycznych schematów zachowań. U dzieci z autyzmem od najwcześniejszych etapów rozwoju występuje zaburzenie kształtowa- nia się prawidłowej relacji z otoczeniem społecznym (Kim, Lord, 2012). W początkowym okresie ujawnia się to w zakłóceniu kształtowania się więzi z bliskimi, zaburzeniach rozwoju kontaktu niewerbalnego - wzrokowego i cielesnego. W późniejszym okresie natomiast objawia się w nieprawidłowej percepcji wzorców społecznych, która wpływa na opóźniony bądź nietypowy rozwój komunikacji językowej 
oraz na kształtowanie się nietypowych schematów zachowań. Niektóre ujęcia teoretyczne wskazują, że objawy występujące w autyzmie moga być związane z zaburzeniem tworzenia koncepcji Ja - która odzwierciedla osobiste pojęcie o byciu człowiekiem podobnym do innych ludzi, a jednocześnie odrębnym i niepowtarzalnym. Koncepcja Ja jest rozumiana jako wyobrażenie i świadomość siebie. Jest to osobiste centrum, z którego postrzegane jest otoczenie - przestrzeń bodźców zmysłowych, obiektów, ludzi (Glezerman, 2013).

Zakłócenie relacji między własną osobą a innymi ludźmi było opisywane jako objaw autyzmu już w najwcześniejszych pracach klinicznych. Sam termin ,,autyzm” (od greckiego autos, czyli Ja) wskazuje na rolę rozwoju sfery intrapsychicznej w kształtowaniu objawów zaburzenia. Termin ten po raz pierwszy został użyty przez Leo Kannera (1943) w odniesieniu do pacjentów pediatrycznych, którzy, według psychiatry, charakteryzowali się ,ekstremalnym skupieniem na sobie”. Współcześnie pośród modeli starających się wyjaśniać poznawcze mechanizmy rozwoju zaburzeń autystycznych część także odwołuje się do aspektów rozwoju wiedzy o samym sobie i własnej tożsamości. Na przykład w modelu zaproponowanym przez Tatyanę Glezerman (2013) objawy ze spektrum autyzmu (ang. autism spectrum disorder - ASD) są związane z zaburzeniem rozwoju reprezentacji własnego Ja. Autorka wskazuje, że osoba z ASD nie odnosi tego, co dzieje się w otoczeniu, do własnej osoby oraz nie rozumie własnej sprawczości. W konsekwencji nie uczy się prawidłowego korzystania ze środków komunikacji, które pośredniczą $\mathrm{w}$ interakcji $\mathrm{z}$ otoczeniem - komunikacji językowej, sygnałów emocjonalnych, zachowania się według ustalonych norm. Glezerman utożsamiła te objawy z nieprawidłowym rozwojem funkcji poznawczych związanych z działaniem tych obszarów czołowych kory mózgowej, które biorą udział w symbolizacji koncepcji Ja (Glezeman, 2013).

W ujęciu Gerharda Boscha (1970) w typowych warunkach, u dzieci rozwijających się bez zaburzeń, rozwój Ja zaczyna się od świadomości własnej aktywności fizycznej i jej konsekwencji. W późniejszym etapie następuje rozwój symbolicznej reprezentacji Ja. Najważniejsze staje się poznanie własnej centralnej pozycji i odnoszenie tego, co dzieje się w otoczeniu, do samego siebie oraz dostrzeganie własnej sprawczości. W swojej książce Infantile Autism G. Bosch wskazywał, że w przypadku dzieci z autyzmem to właśnie rozwój rozumienia relacji między samym sobą a otoczeniem społecznym jest zaburzony. Zaobserwował brak typowej samoświadomości oraz brak poczucia wstydu czy świadomości własności. Stwierdził, że u dzieci tych nie występuja charakterystyczne próby wpływania na innych ludzi za pośrednictwem żądań i próśb, a także brakuje im szerszej świadomości siebie jako jednostki oddziałującej na innych (Bosch, 1970).

Mimo iż od czasu pierwszych opisów klinicznych, zaprezentowanych przez Leo Kannera, identyfikowano znaczenie rozwoju sfery intrapsychicznej i samoświadomości w objawach ASD, problem nie był szeroko eksplorowany w badaniach empirycznych. Przez lata nie dysponowano obiektywnymi metodami badania indywidualnych doświadczeń osób z autyzmem, lecz jedynie obserwacją ich przejawów behawioralnych. Skupiano się przede wszystkim na specyfice rozwoju percepcji podstawowych bodźców społecznych płynących z otoczenia oraz kształtowania się nietypowych zachowań w interakcjach z ludźmi. Kolejne badania wskazują jednak, że do pełnego zrozumienia nieprawidłowości w relacjach społecznych potrzebne jest wyjaśnienie problemu percepcji samego siebie. Jak wspomniano, aspekt postrzegania własnej osoby w przypadku pacjentów z ASD, którzy mają ograniczony wgląd we własne doświadczenie, jest trudny do eksploracji za pomoca metod samoopisowych. Częściowo odpowiedzią na te problemy jest zastosowanie współczesnych metod neuroobrazowania czynnościowego mózgu. Dają one wgląd w obiektywne mechanizmy aktywności neuronalnej towarzyszącej zaangażowaniu określonych procesów psychicznych. Oprócz możliwości udokumentowania markerów biologicznych potencjalnie zaburzonych mechanizmów poznawczych, związanych z tworzeniem reprezentacji Ja u osób z ASD, 
metody neuroobrazowania mózgu przybliżają mechanizm biologiczny leżący u podłoża tych zaburzeń. Należy jednak podkreślić, że ze względu na duże wymagania procedur eksperymentalnych metody te są stosowane w badaniach angażujących określone subpopulacje osób z diagnozą spektrum autyzmu. W najnowszych ujęciach klinicznych spektrum autyzmu jest klasyfikowane na podstawie natężenia symptomów (American Psychiatric Association, 2013). Obecna klasyfikacja, w większym stopniu niż poprzednie, uwzględnia heterogeniczność tej grupy klinicznej, obserwowaną na płaszczyźnie objawów behawioralnych. W artykule przedstawiono przegląd literatury odnoszącej się do badań neuroobrazowania czynnościowego mózgu, dotyczących nastolatków i dorosłych o najmniej nasilonych objawach zaburzeń ze spektrum autyzmu.

\section{BADANIA NEURONALNYCH MECHANIZMÓW PERCEPCJI WLASNEJ OSOBY}

\section{Reprezentacja Ja w badaniach empirycznych}

Problematyka koncepcji Ja jest obszernym zagadnieniem trudnym do jednoznacznej operacjonalizacji. Duża część ujęć teoretycznych wskazuje na wielowymiarowość koncepcji Ja (m.in. James, 1983; Dennett, 1991; Neisser, 1993), odróżniając na przykład aspekt Ja, który bierze udział w interakcji z otoczeniem, komunikuje się i jest postrzegany przez innych, od prywatnego Ja związanego z dostępną tylko jednostce wiedzą na temat samego siebie (Neisser, 1993). Wyróżniany jest obraz Ja obejmujący szersze ramy czasowe, który uwzględnia pamięć autobiograficzną oraz plany na przyszłość (Neisser, 1993; Gallagher, 2000). Wskazuje się także na rolę koncepcji Ja-fizycznego w postrzeganiu własnych możliwości i budowaniu obrazu siebie (Marsh, 1997; 2002). Niewątpliwie Ja funkcjonuje w wielu aspektach, a ich klasyfikację różnicują ujęcia teoretyczne. Na potrzeby badań empirycznych w celu jednoznacznego doboru bodźców eksperymentalnych dokonuje się analizy elementów reprezentacji Ja dających się klasyfikować względem wybranego kryterium. Dzięki temu wyróżniono psychologiczna reprezentacje Ja oraz związany z nią aspekt ciagłości Ja w czasie; symboliczna reprezentację Ja i fizyczna reprezentację Ja. Pierwsza $\mathrm{z}$ wymienionych składowych Ja dotyczy wiedzy na temat własnych cech charakteru, najbardziej typowych zachowań oraz możliwości intelektualnych. Postrzeganie ciagłości Ja w czasie to świadomość niezmienności istoty Ja i jego podstawowych atrybutów mimo możliwości zmiany określonych jego cech, na przykład pod wpływem rozwoju jednostki. Symboliczna reprezentacja $J a$ odnosi się do informacji, z którymi dana osoba się identyfikuje, takich jak imię i nazwisko - one jednak nie informują o atrybutach osoby. Fizyczna reprezentacja $J a$ dotyczy cech fizycznych i obrazu własnego ciała.

\section{Neuronalne korelaty reprezentacji Ja w populacji ogólnej}

W badaniach empirycznych postawiono sobie za cel odpowiedź na pytanie, czy istnieją mechanizmy poznawcze związane jedynie $\mathrm{z}$ tymi aspektami ludzkiego doświadczenia, które dotyczą własnej osoby. Próbowano także rozstrzygnać, w jakim stopniu aspekty te funkcjonują niezależnie od siebie oraz czy istnieje pewien „rdzeń”, który scala te elementy we wspólnej reprezentacji poznawczej. Weryfikacja tych zagadnień stała się częściowo możliwa dzięki rozwojowi współczesnych metod neuroobrazowania mózgu, które dostarczają obiektywnych wskaźników reakcji neuropoznawczych wobec powtarzanych bodźców eksperymentalnych.

W eksperymentach wykorzystywano metody nauroobrazowania funkcjonalnego rezonansu magnetycznego (ang. functional Magnetic Resonance Imaging - fMRI) oraz elektroencefalografii (EEG). Metoda fMRI pozwala na identyfikację obszarów aktywności kory mózgowej w trakcie przetwarzania informacji bądź wykonywania określonych zadań poznawczych. Metoda EEG umożliwia natomiast śledzenie szybkich zmian aktywności elektrycznej mózgu, związanych z rozpoznaniem bodźca, 
zaangażowaniem uwagi i nadaniem mu znaczenia (Polich, 2007). Wyniki współczesnych badań wskazują na istnienie swoistego, podstawowego mechanizmu neuronalnego, specyficznego dla przetwarzania różnorodnych informacji odnoszących się do Ja. W jednym z eksperymentów fMRI prezentowano osobom badanym bodźce, takie jak własna twarz, imię i cechy charakteru. Stwierdzono, że w populacji ogólnej bodźce odnoszące się do własnej osoby - zarówno te dotyczące sfery fizycznej (obraz własnej twarzy, percepcja ciała, cechy fizyczne), jak i te o charakterze symbolicznym (własne imię) i psychologicznym (cechy charakteru, pamięć autobiograficzna) - aktywują struktury mózgowe znajdujące się w obrębie jednej sieci neuronalnej. Uważa się, że są to obszary kory kluczowe $\mathrm{w}$ tworzeniu reprezentacji Ja. Co ciekawe, część z tych obszarów jest także aktywowana podczas percepcji bodźców dotyczących innych osób znanych, a stopień ich aktywacji jest związany ze stopniem „bliskości” osoby, której bodźce dotyczą (Qin, Liu, Shi, Wang, Duncan, Gong, Weng, Northoff, 2012; Tacikowski, Brechmann, Nowicka, 2013; Hu, Di, Eickhoff, Zhang, Peng, Guo, Sui, 2016). W obszernej metaanalizie uwzględniającej 87 badań eksperymentalnych potwierdzono aktywność wybranych struktur mózgu podczas przetwarzania różnorodnych bodźców odnoszących się do Ja (własna twarz, własne imię oraz cechy indywidualne) (Qin, Northoff, 2011). Należą do nich struktury leżące w rejonach czołowych oraz w linii przyśrodkowej mózgu. W szczególności obszar kory w przednim zakręcie obręczy (ang. anterior cingulate cortex - ACC) jest specyficznie zaangażowany podczas przetwarzania bodźców związanych z Ja, w porównaniu z przetwarzaniem bodźców odnoszących się do innych osób (także osobiście znanych) (Qin, Northoff, 2011; Burrows, Laird, Uddin, 2016). Natomiast tylna część kory obręczy (ang. posterior cingulate cortex - PCC) i przyśrodkowa część kory czołowej (ang. medial prefrontal cortex - MPFC) są aktywne podczas przetwarzania bodźców odnoszących się do Ja, a także do osób bliskich i dobrze znanych (Qin, Northoff, 2011; Sugiura, Miyauchi, Kotozaki, Akimoto, Nozawa, Yomogida, Hanawa,
Yamamoto, Sakuma, Nakagawa, Kawashima, 2014). Badacze wskazują również, że te same obszary wchodzą w skład tzw. sieci DMN (ang. default mode network) (np. Knyazev, 2013; Tacikowski, Berger, Ehrsson, 2017; Padmanabhan, Lynch, Schaer, Menon, 2017). Jest to sieć połączeń funkcjonalnych w korze mózgowej, którą identyfikuje się w badaniach fMRI podczas aktywności spoczynkowej, gdy badany nie jest zaangażowany w żadne zadania poznawcze i swobodnie poddaje się własnym myślom oraz stanom wewnętrznym (np. Buckner, Andrews-Hanna, Schacter, 2008; Horn, Ostwald, Reisert, Blankenburg, 2013). Ponadto wykazano, że aktywność struktur w obrębie kory, wykazujących wrażliwość na bodźce związane z własną osobą, jest niezależna od modalności zmysłowej wykorzystywanej do percepcji tych bodźców (Tacikowski i in., 2013). Eksplorując zagadnienie ciągłości Ja w czasie stwierdzono również, że korowe struktury w obrębie linii środkowej mózgu - tylna kora obręczy (PCC) i przyśrodkowa część kory czołowej (MPFC) są aktywowane podczas wykonywania zadania polegającego na przypisywaniu własnej osobie cech zarówno w teraźniejszości, jak i przeszłości (D'Argembeau, Feyers, Majerus, Collette, Van der Linden, Maquet, Salmon, 2008; Cygan, Marchewka, Kotlewska, Nowicka, 2018).

W badaniach neuronalnych korelatów przetwarzania informacji odnoszących się do Ja wykorzystywano także rejestrację EEG. Metoda ta pozwala na śledzenie charakterystycznych elementów aktywności elektrycznej mózgu z dużą dokładnością czasową. Dzięki zastosowaniu metody EEG możliwa jest ocena, w jakim stopniu bodźce odnoszące się do własnej osoby są przetwarzane w sposób preferencyjny (szybszy bądź bardziej angażujący) w stosunku do innych bodźców (Luck, Woodman, Vogel 2000). Badania EEG dotyczące populacji ogólnej wskazuja, że rozpoznawanie bodźców odnoszących się do Ja, jako szczególnie znaczących, odzwierciedla się przede wszystkim w większych amplitudach załamka P300 potencjałów wywołanych oraz w zmianach częstotliwościowych w obrębie pasma alfa (Polich, 2007; Knyazev, 2013; Tacikowski, Cygan, Nowicka, 2014; Woźniak, Kourtis, Knoblich, 2018). 


\section{MÓZGOWE KORELATY \\ PRZETWARZANIA INFORMACJI O WLASNEJ OSOBIE W AUTYZMIE}

Identyfikacja charakterystycznych cech percepcji informacji odnoszących się do Ja w populacji ogólnej zainicjowała poszukiwania nietypowych mechanizmów neuronalnych towarzyszących percepcji bodźców związanych z Ja w populacjach klinicznych, w tym osób z zaburzeniami ze spektrum autyzmu. Biorąc pod uwagę wcześniejsze opracowania kliniczne i wyniki badań empirycznych, badacze coraz częściej wskazywali na potrzebę badania sfery intrapsychicznej w odniesieniu do osób ze spektrum autyzmu. Michael Lombardo i Simon Baron-Cohen (2011) zasugerowali, że osoby z ASD mogą charakteryzować się jednocześnie ekstremalnym egocentryzmem oraz deficytem w poznawczym przetwarzaniu informacji związanych z Ja. Według nich nietypowe cechy przetwarzania informacji o własnej osobie mają podłoże w zaburzeniu funkcjonowania opisanych wcześniej obszarów kory czołowej i przyśrodkowej mózgu. W istocie badania empiryczne sukcesywnie potwierdzaja te przypuszczenia. W dalszej części artykułu zostaną przedstawione wyniki badań przeprowadzonych $\mathrm{z}$ zastosowaniem wybranych metod neuroobrazowania - EEG oraz fMRI. Eksplorują one problematykę percepcji własnej osoby przez pacjentów z ASD, odwołując się do mechanizmów opisanych wcześniej w badaniach populacji ogólnej. Przeprowadzone eksperymenty poszukują odpowiedzi na pytania, czy oraz jakie mechanizmy neuronalne moga świadczyć o nietypowych cechach postrzegania i poznawczego przetwarzania informacji, które odnoszą się do Ja. W szczególności zajęto się weryfikacją hipotez mówiących o tym, że u osób z ASD bodźce związane z Ja - przeciwnie niż w populacji neurotypowej-nie są postrzegane w sposób specyficzny i preferencyjny. Przedstawiony dalej przegląd literatury odnosi się do badań tych elementów reprezentacji Ja, które były przedmiotem zainteresowania testów prowadzonych na populacji ogólnej. Dotyczy postrzegania psychologicznych aspektów własnej osoby - własnych cech i typowych sposobów zachowania, oraz aspektów symbolicznych i fizycznych - między innymi własnego imienia oraz percepcji własnej twarzy czy ciała. Dodatkowo przedstawiono wyniki eksperymentu, w którym po raz pierwszy podjęto problematykę neuronalnych korelatów percepcji ciagłości Ja oraz funkcjonowania pamięci autobiograficznej u osób z ASD.

\section{Psychologiczna reprezentacja Ja}

Osobiste przekonania na temat własnych cech charakteru, najbardziej typowych zachowań oraz możliwości intelektualnych przypisywane są psychologicznym aspektom reprezentacji Ja (Uddin, 2011). Jak wykazały badania z wykorzystaniem technik neuroobrazowania, taka ocena własnych cech u osób neurotypowych jest silnie powiązana $\mathrm{z}$ aktywacjami struktur położonych w linii środkowej mózgu: tylnej części zakrętu obręczy (ang. posterior cingulate cortex - PCC) i przyśrodkowej części kory przedczołowej (ang. medial prefrontal cortex - mPFC), wchodzących w skład sieci DMN (Raichle, MacLeod, Snyder, Powers, Gusnard, Shulman, 2001; Padmanabhan $\mathrm{i}$ in., 2017; Tacikowski i in., 2017).

W odniesieniu do populacji osób z ASD jednym z pierwszych badań, które ujawniło, że osoby z tej grupy klinicznej charakteryzują się nietypową aktywnością kory mózgowej podczas oceny własnych cech, było badanie Daniela Kennedy'ego i Erica Courchesne'a (2008). W eksperymencie fMRI wykazali oni, że w grupie nastolatków i dorosłych z ASD występuje obniżona aktywacja w brzuszno-przyśrodkowych obszarach kory przedczołowej. Różnice między grupą ASD a kontrolną wystąpiły zarówno w warunku oceny cech własnych, jak i warunku oceny cech bliskiej osoby (Kennedy i Courchesne, 2008). W badaniach M. Lombarda i in. (2010) również wykazano, że u osób z ASD występują nietypowe aktywacje w brzuszno-przyśrodkowym obszarze kory czołowej. W przebadanej grupie odnotowano aktywacje wspomnianych obszarów kory podczas odnoszenia cech fizycznych i psychologicznych do własnej osoby (ang. self-mentalizing), jak również do powszechnie znanej osoby 
- królowej angielskiej (badania prowadzono na populacji brytyjskiej). W grupie neurotypowej te same obszary kory były aktywowane jedynie przy określaniu cech odnoszących się do własnej osoby, wykazując większą specjalizację wobec warunku „Ja” (Lombardo, Charkrabarti, Bullmore, Sadek, Pasco., Wheelwright, Suckling, Baron-Cohen, 2010). W kolejnym eksperymencie z zastosowaniem metody fMRI przebadano nastolatków z ASD (ze średnią wieku 13 lat) podczas dokonywania oceny, czy krótkie stwierdzenia odnoszą się do Ja (Pfeifer, Merchant, Colich, Hernandez, Rudie, Dapretto, 2013). Stwierdzenia dotyczyły kompetencji społecznych oraz kompetencji szkolnych. W warunku kontrolnym do warunku Ja badani odpowiadali, czy analogiczne stwierdzenia odnoszą się do postaci tytułowego bohatera książki Harry'ego Pottera. Podobnie jak w badaniach Kennedy'ego i Courchesne'a (2008) wykazano, że podczas oceny własnych cech występuje obniżona aktywność w przyśrodkowej korze przedczołowej (mPFC). Dodatkowo u dzieci z ASD bardziej nietypowa aktywność w wyspie oraz w środkowej części zakrętu obręczy (ang. middle cingulate cortex - MCC) była związana ze zdiagnozowanym zakresem objawów spektrum autyzmu (Pfeifer i in., 2013). W przypadku MCC grupa kontrolna aktywowała ten obszar w większym stopniu podczas oceny własnych cech niż podczas oceny cech innej osoby. W grupie ASD zależność miała charakter odwrotny - MCC aktywowane było silniej podczas przypisywania cech innej osobie niż podczas przypisywania cech sobie. Zbliżone zależności między zakresem zaburzeń a aktywnością w MCC uzyskano we wcześniejszym eksperymencie z udziałem dorosłych z ASD (Lombardo i in., 2010).

Opisane eksperymenty konsekwentnie wskazują, że w grupie ASD występują nieprawidłowości funkcjonalne w strukturach typowo zaangażowanych $\mathrm{w}$ przetwarzanie informacji o sobie oraz o innych osobach - w brzuszno-przyśrodkowych obszarach kory czołowej i w zakręcie obręczy. Wymienione struktury wykazują obniżoną aktywność w czasie przetwarzania informacji o Ja bądź mniejszą selektywność w stosunku do tego typu informacji (tj. są aktywne w podobnym stopniu także podczas przetwarzania informacji o innych osobach). W kolejnych badaniach starano się rozstrzygnąć, jak wymienione obszary kory komunikują się ze sobą oraz z innymi strukturami stanowiącymi sieć DMN. Wykorzystano między innymi procedurę analizy połączeń funkcjonalnych w odniesieniu do danych $\mathrm{z}$ aktywności spoczynkowej (ang. resting state functional connectivity) $\mathrm{z}$ rejestracji fMRI, w różnych grupach wiekowych osób z ASD. Wyniki wykazały, że w grupie dzieci z ASD występuje obniżona siła połączeń funkcjonalnych między obszarem specyficznym dla percepcji bodźców odnoszących się do Ja (MPFC) a obszarem związanym z percepcją bodźców odnoszących się do innych osób (PCC) (Burrows $i$ in., 2016) (rysunek 1). Komunikacja między tymi obszarami wydaje się istotna $\mathrm{w}$ rozwoju wiedzy na temat relacji między własną osobą a otoczeniem społecznym oraz $\mathrm{w}$ nabywaniu prawidłowych zachowań na podstawie doświadczeń z interakcji z ludźmi. Dodatkowo należy podkreślić, że w opisanych badaniach mniejsza siła połączeń funkcjonalnych dotyczyła dzieci, ale nie dorosłych z ASD. Wynik wskazuje na zmienność komunikacji między omawianymi obszarami kory, powiązaną ze zmiennością cech rozwojowych, obserwowaną na różnych jego etapach u osób z diagnozą spektrum autyzmu (Burrows i in., 2016). Ponadto wyniki badań połączeń funkcjonalnych nie są jednoznaczne, wykazują bowiem zarówno obniżoną, jak i podwyższoną siłę połączeń w obrębie sieci DMN (Lynch, Uddin, Supekar, Khouzam, Phillips, Menon, 2013; Uddin, Supekar, Lynch, Khouzam, Phillips, Feinstein, Ryali, Menon, 2013). Wydaje się, że efekty są w dużej mierze zależne od doboru specyficznych podregionów kory mózgowej do badania i analizowanych połączeń funkcjonalnych sieci, jak również od wieku osób biorących udział w eksperymencie (Washington, Gordon, Brar, Warburton, Sawyer, Wolfe, Mease-Ference, Girton, Hailu, Mbwana, Gaillard, Kalbfleisch, VanMeter, 2014; Burrows i in., 2016). Część wyników wykazała, że rezultaty obserwowane na przykład w grupie nastolatków z ASD są charakterystyczne dla młodszych dzieci z populacji 


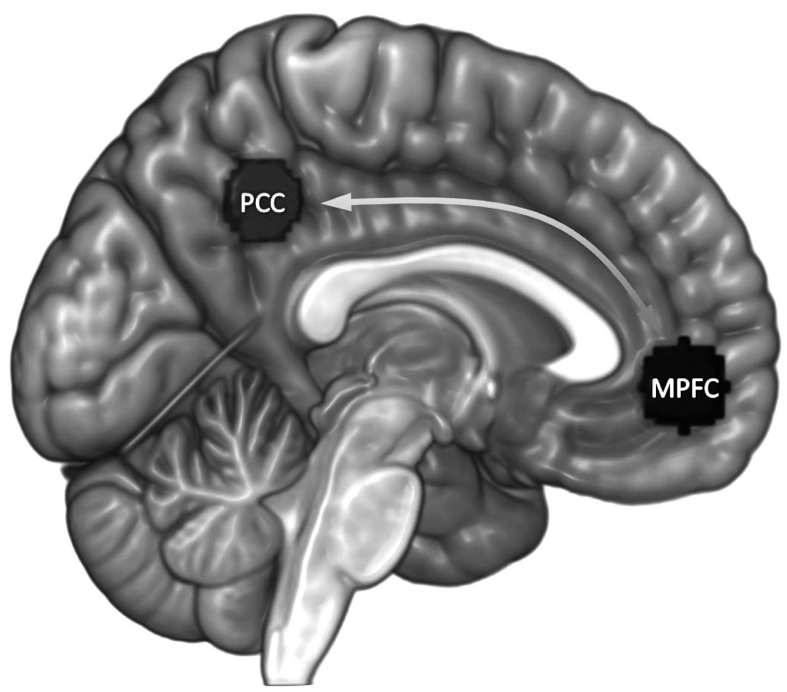

Rysunek 1. Obszary kory mózgu należące do sieci DMN, zaangażowane w przetwarzanie bodźców dotyczących Ja (MPFC) oraz bodźców społecznych (PCC). Kolorem szarym oznaczono obszar tylnego zakrętu obręczy (PCC - posteriori cingulate cortex), kolorem czarnym oznaczono obszar przyśrodkowej kory przedczołowej (MPFC - medial prefrontal cortex), a strzałka obrazuje interakcję między PCC a MPFC. (ilustracja poglądowa)

Źródło: opracowanie własne.

neurotypowej, co może wynikać z opóźnienia rozwoju połączeń funkcjonalnych w sieci DMN (Washington $\mathrm{i}$ in., 2014).

\section{Fizyczna i symboliczna reprezentacja Ja}

Poznawcza reprezentacja własnej osoby może się także odnosić do aspektów o charakterze symbolicznym, takich jak własne imię, oraz o charakterze fizycznym czy „ucieleśnionym”, związanych z obrazem ciała i rozpoznawaniem własnej twarzy. Od pierwszych tygodni życia dziecko jest eksponowane na różnego typu bodźce odnoszące się do jego osoby. Przed ukończeniem 6. miesiąca życia zaczyna wyróżniać własne imię (Mandel, Jusczyk, Pisoni, 1995; Bortfeld, Morgan, Golinkoff, Rathbun, 2005), a przed ukończeniem 2. roku potrafi rozpoznać swoje odbicie w lustrze (Amsterdam, 1972). Co ważne, brak typowej reakcji na własne imię we wczesnym okresie rozwoju bywa jednym z pierwszych symptomów, które mogą świadczyć o ryzyku zaburzeń ze spektrum autyzmu (np. Osterling, Dawson, 1994; Nadig, Ozonoff, Young, Rozga, Sigman, Rogers, 2007; Miller, Iosif, Hill, Young, Schwichtenberg, Ozonoff, 2017). Kilka z przeprowadzonych dotychczas eksperymentów badało, jak u osób z ASD przebiegają mechanizmy neuronalne związane z postrzeganiem własnej twarzy oraz z reakcja na swoje imię. W serii badań elektrofizjologicznych wykazano w grupie nastolatków i dorosłych z ASD brak typowego, preferencyjnego zaangażowania uwagi automatycznej wobec własnej twarzy oraz imion i nazwisk (Cygan, Tacikowski, Ostaszewski, Chojnicka, Nowicka, 2014). W badaniu zastosowano rejestrację aktywności neuronalnej za pomocą EEG. Pośród bodźców były te, które dotyczyły własnej osoby, jak również bodźce dotyczące osób znanych osobiście (np. członek rodziny, przyjaciel), znanych powszechnie (aktor, polityk) i nieznanych. $\mathrm{W}$ miarach behawioralnych nie stwierdzono różnic międzygrupowych w czasach reakcji oraz w poprawności odpowiedzi. Różnice wystąpiły na poziomie odpowiedzi neuronalnej. 
W grupie kontrolnej w zapisie sygnału EEG odnotowano typowe efekty wzmożonej aktywności neuronalnej, odzwierciedlonej podwyższoną amplitudą P300 mózgowych potencjałów wywołanych, pojawiających się w odpowiedzi na własne imię i nazwisko, oraz jako reakcje na własną twarz. W przypadku grupy klinicznej nie wystapiło - odzwierciedlone w amplitudach potencjałów wywołanych - różnicowanie między własną osobą a dobrze znaną osobą bliską (Cygan i in., 2014). Podobny wynik otrzymano wtedy, gdy osoby badane były zaangażowane w intencjonalne różnicowanie imion i nazwisk (własnych, osób bliskich oraz znanych i nieznanych) (Nowicka, Cygan, Tacikowski, Ostaszewski, Kuś, 2016). Przedstawione wyniki potwierdziły wcześniejsze doniesienia o prawidłowościach w percepcji twarzy (własnej oraz znanych i nieznanych) (Gunji, Inagaki, Inoue, Takeshima, Kaga, 2009). Kolejne badania ujawniły, że brak preferencji dla własnego imienia występuje także w odniesieniu do bodźców prezentowanych słuchowo. W eksperymencie, w którym osoby badane słyszały wypowiadane imiona, stwierdzono, że u dorosłych osób z ASD nie występuje typowa preferencja dla własnego imienia, odzwierciedlona amplitudą późnej fali pozytywnej (ang. late positive potential - LPP) w sygnale EEG (Nijhof, Dhar, Goris, Brass, Wiersema, 2018).

Badania dotyczące mechanizmów postrzegania własnej twarzy u osób z ASD były prowadzone także z wykorzystaniem metody fMRI. W jednym $\mathrm{z}$ nich rejestrowano odpowiedź neuronalną u dzieci z ASD (średnia wieku 13 lat) oraz dzieci rozwijających się typowo podczas dokonywania oceny, czy prezentowana twarz jest twarzą własną czy innej osoby. Bodźcami zastosowanymi w badaniu były obrazy twarzy stworzone przez połączenie dwóch innych twarzy. Każde zdjęcie składało się w różnym procencie z twarzy własnej oraz z twarzy należącej do innej osoby dobranej pod względem płci. W grupie ASD jedynie podczas obserwacji twarzy, które w większym procencie składały się z własnej, stwierdzono aktywację w korze przedczołowej prawej półkuli mózgu. U osób z grupy kontrolnej natomiast te same obszary kory były aktywne również podczas obserwacji twarzy, w których dominował obraz innej osoby (Uddin, Davies, Scott, Zaidel, Bookheimer, Iacoboni, Dapretto, 2008). W interpretacji wyników autorzy sugerują, iż badani z ASD w mniejszym stopniu niż osoby z populacji ogólnej uaktywniają wspólne reprezentacje korowe wobec bodźców reprezentujących Ja oraz bodźców, które odnoszą się do innych osób (Uddin i in., 2008). W jednym z nowszych badań stwierdzono także, że u badanych z ASD występuje słabszy efekt wzbudzenia emocjonalnego oraz sprzężenia między poznawczą i emocjonalną reakcją wobec własnej twarzy. Stopień zakłopotania, związany z obserwacją własnej twarzy, był pozytywnie skorelowany z aktywnością w przedniej korze wyspy prawej półkuli mózgu u osób neurotypowych, ale nie w grupie ASD. Dodatkowo świadomość bycia obserwowanym w trakcie badania u osób z grupy kontrolnej zwiększała siłę komunikacji neuronalnej między przednim zakrętem obręczy (ACC) a przyśrodkową korą przedczołową (MPFC). W grupie badanych osób z ASD efekt ten nie wystapił (Morita, Kosaka, Saito, Fujii, Ishitobi, Munesue, Inohara, Okazawa, Kakigi, Sadato, 2016).

Powyższe badania potwierdzają występowanie u osób z ASD nieprawidłowości w neuronalnych korelatach poznawczego przetwarzania charakterystycznych bodźców, takich jak własna twarz oraz własne imię i nazwisko. Badania elektrofizjologiczne wskazują na mechanizm związany z procesami wzbudzenia uwagi (Polich, 2007) i emocji (Dietrich, Waller, Johannes, Wieringa, Emrich, Munte, 2001), odzwierciedlonej w tzw. późnych komponentach potencjałów wywołanych (P300, późna fala pozytywna) (Cygan i in., 2014; Nijhof $\mathrm{i}$ in., 2018). Badania fMRI wykazały natomiast nieprawidłowości funkcjonalne w strukturach kory mózgowej, które są związane z tworzeniem szerszej reprezentacji Ja (Qin, Northoff, 2011) - w przyśrodkowej korze czołowej oraz zakręcie obręczy i wyspie.

\section{Pamięć autobiograficzna}

Pamięć autobiograficzna stanowi część pamięci dotyczącej osobistej przeszłości jednostki. Zawiera wspomnienia związane $\mathrm{z}$ tożsamością 
człowieka, powiązane z osobistym doświadczeniem i emocjami. Definiuje „kim jesteśmy, kim byliśmy i - co ważniejsze - kim możemy się stać" (Rybak-Korneluk, Wichowicz, Żuk, Dziurkowski, 2016). Stanowi zatem jeden z podstawowych procesów poznawczych, biorących udział w kształtowaniu umysłowego obrazu własnej osoby. Świadomość osobistych zmian, zachodzących w trakcie życia, wymaga umiejętności rozróżniania reprezentacji samego siebie w chwili obecnej i z przeszłości (McAdams, 2001). Pozwala na budowanie świadomości „ciągłości Ja” w czasie - postrzeganie aspektów niezmiennych, konstytuujących osobowość i tożsamość jednostki. Jednocześnie umożliwia także dostrzeganie aspektów zmiennych własnej charakterystyki, które wynikają z rozwoju osobistego (Rybak-Korneluk i in., 2016).

W badaniach wykorzystujących metody behawioralne wykazano, że u osób z ASD występują trudności w przypominaniu sobie przeszłości - przeżytych zdarzeń oraz faktów (Brezis, 2015). Osoby z ASD przypominają sobie mniej zdarzeń z przeszłości oraz, co ważne, zajmuje im to istotnie więcej czasu (Adler, Nadler, Eviatar, Shamay-Tsoory, 2010). Wyniki wskazuja, że sięganie do osobistych wspomnień jest dla osób z ASD zadaniem trudnym, wymagającym wysiłku i zaangażowania poznawczego. Powyższy wniosek został pośrednio zweryfikowany w eksperymencie z zastosowaniem obrazowania mózgu metodą fMRI (Cygan i in., 2018). Przebadano w nim, jak w grupie osób z ASD oraz w grupie dobranych do niej osób kontrolnych przebiegają procesy mózgowe towarzyszące świadomej refleksji na temat obecnych atrybutów własnej osoby, jak również atrybutów retrospektywnie przypisywanych własnej osobie z wyznaczonego okresu w przeszłości. W wyniku eksperymentu na poziomie behawioralnym stwierdzono, że w grupie klinicznej przypisywano własnej osobie sprzed kilku lat mniej cech pozytywnych niż w grupie kontrolnej. Dodatkowo w obrębie grupy kontrolnej wystapiła typowa tendencja do przypisywania sobie dużo większej liczby cech pozytywnych niż negatywnych. Na poziomie aktywności neuronalnej u osób z ASD refleksja na temat własnej osoby z przeszłości była związana z zaangażowaniem dodatkowych struktur mózgu (tylna część zakrętu obręczy oraz tylna część kory skroniowej). Ta wzmożona aktywacja dużych obszarów sieci neuronowych prawdopodobnie odzwierciedla trudności w przetwarzaniu informacji na temat własnej osoby z przeszłości. Wnioski z badania sugerują, że osoby z ASD mogą mieć trudność w efektywnym wykorzystaniu tych funkcji poznawczych i aktywują dodatkowe procesy, by poradzić sobie z zadaniem oceny własnych cech. Aby skompensować zaburzenia pamięci autobiograficznej oraz właściwego postrzegania ciągłości własnej osoby, uruchamiają dodatkowe procesy poznawcze związane z wyobraźnią oraz pamięcią konkretnych zdarzeń i faktów (Cygan i in., 2018).

\section{PODSUMOWANIE}

Przeprowadzone dotychczas badania dostarczają dowodów na zaburzenie neuronalnych mechanizmów związanych z tworzeniem poznawczej reprezentacji Ja oraz odnoszeniem informacji społecznych do własnej osoby, wśród pacjentów z ASD. Dostrzeganie własnej roli oraz rozumienie relacji Ja-inni jest niezbędne w kształtowaniu prawidłowych interakcji społecznych (Banaji, Prentice, 1994). Uważa się, że osoby z ASD mają trudności w uczestniczeniu we wzajemnej relacji z innymi, zarówno z powodu zaburzenia rozumienia stanów mentalnych drugiego człowieka, jak i z powodu zaburzonej percepcji własnej osoby. Wiedza płynąca z badań eksperymentalnych potwierdza te hipotezy. Badania neuronalnych mechanizmów towarzyszących specyficznym zaburzeniom percepcji Ja uwypuklają rolę systemów funkcjonalnych kory mózgowej w obrębie płatów czołowych i zakrętu obręczy. Stwierdzone nieprawidłowości dotyczą zarówno aspektów fizycznych i symbolicznych odnoszących się do Ja (Cygan i in., 2014; Nijhof i in., 2018), jak i aspektów psychologicznych (Uddin i in., 2008; Lombardo i in., 2010; Pfeifer i in., 2013; Morita $\mathrm{i}$ in, 2016; Cygan i in., 2018). Wiele wskazuje na to, że w przypadku dorosłych osób z ASD bodźce dotyczące Ja są traktowane mniej selektywnie przez mózgowe systemy percepcyjno- 
-poznawcze (np. Lombardo i in., 2010; Cygan $\mathrm{i}$ in., 2014; Cygan i in., 2018). U podłoża tych nieprawidłowości prawdopodobnie stoi bardziej podstawowy mechanizm zaburzeń połączeń funkcjonalnych w korze mózgowej, które w typowych warunkach umożliwiają dziecku rozwój poznawczych reprezentacji samego siebie i otoczenia społecznego oraz rozumienia dynamicznych interakcji między tymi sferami (Burrows i in., 2016; Padmanabhan i in., 2017). Odkryte zaburzenia neuropoznawcze mogą tłumaczyć szersze spektrum zachowań autystycznych. Odniesienie wiedzy na temat siebie do wiedzy na temat innych jest kluczowe w utrwalaniu i korygowaniu prawidłowych zachowań, w skutecznym komunikowaniu się oraz w przyswajaniu zasad współżycia społecznego.

Co ciekawe, różnice wykrywane u dorosłych osób z ASD na poziomie neuronalnym często są mniej widoczne w wynikach testów behawioralnych (np. Cygan i in., 2018; Nijhof i in., 2018; Cygan i in., 2014;). Ta rozbieżność może sugerować, że nieprawidłowości w przetwarzaniu określonych typów informacji, stwierdzane u osób ze spektrum autyzmu, są kompensowane w trakcie rozwoju, jednakże ich ślady są nadal obecne w zaburzonym mechanizmie neurofizjologicznym. Należy także podkreślić, że w badaniach neuroobrazowania, ze względu na wymagającą procedurę, biorą udział osoby $\mathrm{z}$ autyzmem tzw. wysoko funkcjonujące (ang. high functionning ASD). Implikuje to ograniczenia we wnioskowaniu na temat całej populacji osób z ASD. Wydaje się, że odkryte mechanizmy neuronalne mogą być wyraźniejsze bądź mogą przyjmować nieco inny kształt u osób, u których zaburzenia ze spektrum autystycznego są dużo głębsze. Różnice mogą być także związane ze zmiennością rozwojową, na co wskazuje odnotowana u dzieci, ale nie u dorosłych osób z ASD, obniżona siła połączeń między obszarami kory w obrębie sieci DMN (Burrows i in., 2016). Wyniki badań eksperymentalnych nie pozwalają zatem na uogólnione wnioski dotyczące całej populacji osób z ASD. Wskazują raczej na złożoność problemu percepcji Ja na tle szerszego kontekstu społecznego poznania, na który nakładają się zmienne cechy rozwojowe oraz heterogeniczność tej grupy klinicznej.

\section{BIBLIOGRAFIA}

Adler N., Nadler B., Eviatar Z., Shamay-Tsoory S.G. (2010), The relationship between theory of mind and autobiographical memory in high-functioning autism and Asperger syndrome. Psychiatry Research, 178(1), 214-216.

Amsterdam B. (1972), Mirror self-image reactions before age two. Developmental Psychobiology: The Journal of the International Society for Developmental Psychobiology, 5(4), 297-305.

American Psychiatric Association (2013), Diagnostic and statistical manual of mental disorders (5 $5^{\text {th }}$ ed.). Arlington, VA: Author.

Banaji M.R., Prentice D.A. (1994), The self in social contexts. Annual Review of Psychology, 45(1), 297-332.

Bortfeld H., Morgan J.L., Golinkoff R.M., Rathbun K. (2005), Mommy and me: Familiar names help launch babies into speech-stream segmentation. Psychological Science, 16(4), 298-304.

Bosch G. (1970). Infantile autism. New York: Springer-Verlag.

Brezis R.S. (2015), Memory integration in the autobiographical narratives of individuals with autism. Frontiers in Human Neuroscience, 9, 76.

Buckner R.L., Andrews-Hanna J.R., Schacter D.L. (2008), The Brain's Default Network: Anatomy, Function, and Relevance to Disease. Annals of the New York Academy of Sciences 1124 (1), 1-38.

Burrows C.A., Laird A. R., Uddin L.Q. (2016), Functional connectivity of brain regions for self- and othervaluation in children, adolescents and adults with autism. Developmental Science, 19(4), 564-580.

Cygan H.B., Marchewka A., Kotlewska I., Nowicka A. (2018), Neural Correlates of Reflection on Present and Past Selves in Autism Spectrum Disorder. Journal of Autism and Developmental Disorders, 1-11.

Cygan H.B., Tacikowski P., Ostaszewski P., Chojnicka I., Nowicka A. (2014), Neural correlates of own name and own face detection in autism spectrum disorder. PLoS One, 9(1), e86020. 
D’Argembeau A., Feyers D., Majerus S., Collette F., Van der Linden M., Maquet P., Salmon E. (2008), Selfreflection across time: cortical midline structures differentiate between present and past selves. Social Cognitive and Affective Neuroscience, 3(3), 244-252.

Dennett D.C. (1991), Consciousness explained. Boston: Little, Brown and Company.

Dietrich D.E., Waller C., Johannes S., Wieringa B.M., Emrich H.M., Munte T.F. (2001), Differential effects of emotional content on event-related potentials in word recognition memory. Neuropsychobiology, 43, 96-101.

Gallagher S. (2000), Philosophical conceptions of the self: Implications for cognitive science. Trends in Cognitive Sciences, 4(1), 14-21.

Glezerman T. (2013), Autistic person's sense of self. W: Autism and the Brain, 194. New York: Springer.

Gunji A., Inagaki M., Inoue Y., Takeshima Y., Kaga M. (2009), Event-related potentials of self-face recognition in children with pervasive developmental disorders. Brain and Development, 31, 139-147.

Horn A., Ostwald D., Reisert M., Blankenburg F. (2013), The structural-functional connectome and the default mode network of the human brain. NeuroImage, 102, 142-151.

Hu C., Di X., Eickhoff S. B., Zhang M., Peng K., Guo H., Sui J. (2016), Distinct and common aspects of physical and psychological self-representation in the brain: A meta-analysis of self-bias in facial and selfreferential judgements. Neuroscience \& Biobehavioral Reviews, 61, 197-207.

James W. (1983), The principles of psychology. Cambridge: Harvard University Press.

Kanner L. (1943), Autistic disturbances of affective contact. Nervous Child, 2, 217-250.

Kennedy D.P., Courchesne E. (2008), Functional abnormalities of the default network during self- and otherreflection in autism. Social Cognition and Affective Neuroscience, 3(2), 177-190.

Kim S.H., Lord C. (2012), New autism diagnostic interview-revised algorithms for toddlers and young preschoolers from 12 to 47 months of age. Journal of Autism and Developmental Disorders, 42(1), 82-93.

Knyazev G. (2013), EEG correlates of self-referential processing. Frontiers in Human Neuroscience, 7, 264.

Lombardo M.V., Baron-Cohen S. (2011), The role of the self in mindblindness in autism. Consciousness and Cognition, 20(1), 130-140.

Lombardo M.V., Charkrabarti B., Bullmore E.T., Sadek S.A., Pasco G., Wheelwright S.J., Suckling J., Baron-Cohen S. (2010), Atypical neural self-representation in autism. Brain, 133(2), 611-624.

Luck S.J., Woodman G.F., Vogel E.K. (2000), Event-related potential studies of attention. Trends in Cognitive Sciences, 4(11), 432-440.

Lynch C.J., Uddin L.Q., Supekar K., Khouzam A., Phillips J., Menon V. (2013), Default mode network in childhood autism: posteromedial cortex heterogeneity and relationship with social deficits. Biological Psychiatry, 74 (3), 212-219.

Marsh H.W. (1997), The measurement of physical self-concept: A construct validation approach. W: K.R. Fox (eds.), The Physical Self: From Motivation to Well-Being, 27-58. Champaign, IL, US: Human Kinetics.

Marsh H.W. (2002), A multidimensional physical self-concept: A construct validity approach to theory, measurement and research. Psychology: The Journal of the Hellenic Psychological Society, 9, 459-493.

Mandel D.R., Jusczyk P.W., Pisoni D.B. (1995), Infants' recognition of the sound patterns of their own names. Psychological Science, 6(5), 314-317.

McAdams D.P. (2001), The psychology of life stories. Review of General Psychology, 5(2), 100.

Miller M., Iosif A.M., Hill M., Young G.S., Schwichtenberg A.J., Ozonoff S. (2017), Response to name in infants developing autism spectrum disorder: A Prospective Study. The Journal of Pediatrics, 183, 141-146.

Morita T., Kosaka H., Saito D.N., Fujii T., Ishitobi M., Munesue T., Inohara T., Okazawa H., Kakigi R., Sadato N. (2016), Neural correlates of emotion processing during observed self-face recognition in individuals with autism spectrum disorders. Research in Autism Spectrum Disorders, 26, 16-32.

Nadig A.S., Ozonoff S., Young G.S., Rozga A., Sigman M., Rogers S.J. (2007), A prospective study of response to name in infants at risk for autism. Archives of Pediatrics \& Adolescent Medicine, 161(4), 378-383.

Neisser U. (1993), The perceived self: Ecological and interpersonal sources of self-knowledge. Cambridge: Cambride University Press.

Nijhof A.D., Dhar M., Goris J., Brass M., Wiersema J.R. (2018), Atypical neural responding to hearing one's own name in adults with ASD. Journal of Abnormal Psychology, 127(1), 129.

Nowicka A., Cygan H.B., Tacikowski P., Ostaszewski P., Kuś R. (2016), Name recognition in autism: EEG evidence of altered patterns of brain activity and connectivity. Molecular Autism, 7(1), 38. 
Osterling J., Dawson G. (1994), Early recognition of children with autism: A study of first birthday home videotapes. Journal of Autism and Developmental Disorders, 24(3), 247-257.

Padmanabhan A., Lynch C. J., Schaer M., Menon V. (2017), The default mode network in autism. Biological Psychiatry: Cognitive Neuroscience and Neuroimaging, 2(6), 476-486.

Pfeifer J.H., Merchant J.S., Colich N.L., Hernandez L.M., Rudie J.D., Dapretto M. (2013), Neural and behavioral responses during self-evaluative processes differ in youth with and without autism. Journal of Autism and Developmental Disorders, 43(2), 272-285.

Polich J. (2007), Updating P300: An integrative theory of P3a and P3b. Clinical Neurophysiology, 118, 2128-2148.

Qin P., Northoff G. (2011), How is our self-related to midline regions and the default-mode network? Neuroimage, 57(3), 1221-1233.

Qin P., Liu Y., Shi J., Wang Y., Duncan N., Gong Q., Weng X., Northoff G. (2012), Dissociation between anterior and posterior cortical regions during self-specificity and familiarity: A combined fMRI-meta-analytic study. Human Brain Mapping, 33(1), 154-164.

Raichle M.E., MacLeod A.M., Snyder A.Z., Powers W.J., Gusnard D.A., Shulman G.L. (2001), A default mode of brain function. Proceedings of the National Academy of Sciences, 98(2), 676-682.

Rybak-Korneluk A., Wichowicz H.M., Żuk K., Dziurkowski M. (2016), Pamięć autobiograficzna i jej znaczenie w wybranych zaburzeniach psychicznych. Psychiatria Polska, 50, 959-972.

Sugiura M., Miyauchi C.M., Kotozaki Y., Akimoto Y., Nozawa T., Yomogida Y., Hanawa S., Yamamoto Y., Sakuma A., Nakagawa S., Kawashima R. (2014), Neural mechanism for mirrored self-face recognition. Cerebral Cortex, 25(9), 2806-2814.

Tacikowski P., Berger C.C., Ehrsson H.H. (2017), Dissociating the neural basis of conceptual self-awareness from perceptual awareness and unaware self-processing. Cerebral Cortex, 27(7), 3768-3781.

Tacikowski P., Brechmann A., Nowicka A. (2013), Cross-modal pattern of brain activations associated with the processing of self- and significant other's name. Human Brain Mapping, 34, 2069-2077.

Tacikowski P., Cygan H.B., Nowicka A. (2014), Neural correlates of own and close-other's name recognition: ERP evidence. Frontiers in Human Neuroscience, 8, 194.

Tacikowski P., Jednorog K., Marchewka A., Nowicka A. (2011), How multiple repetitions influence the processing of self-, famous and unknown names and faces: an ERP study. International Journal of Psychophysiology, 79, 219-230.

Uddin L.Q. (2011), The self in autism: an emerging view from neuroimaging. Neurocase, 17(3), 201-208.

Uddin L.Q., Davies M.S., Scott A.A., Zaidel E., Bookheimer S.Y., Iacoboni M., Dapretto M. (2008), Neural basis of self and other representation in autism: an FMRI study of self-face recognition. PloS One, 3(10), e3526.

Uddin L.Q., Supekar K., Lynch C.J., Khouzam A., Phillips J., Feinstein C., Ryali S., Menon V. (2013), Salience network-based classification and prediction of symptom severity in children with autism. JAMA Psychiatry, 70 (8), 869-879.

Washington S.D., Gordon E.M., Brar J., Warburton S., Sawyer A.T., Wolfe A., Mease-Ference E.R., Girton L., Hailu A., Mbwana J., Gaillard W.D., Kalbfleisch M.L., VanMeter J.W. (2014), Dysmaturation of the default mode network in autism. Human Brain Mapping, 35(4), 1284-1296.

Woźniak M., Kourtis D., Knoblich G. (2018), Prioritization of arbitrary faces associated to self: An EEG study. PloS One, 13(1), e0190679. 